\title{
The application of augmented reality in elementary school education
}

\author{
A aplicação da realidade aumentada no ensino fundamental \\ La aplicación de la realidad aumentada en la educación primaria
}

Received: 02/10/2021 | Reviewed: 02/16/2021 | Accept: 03/04/2021 | Published: 03/10/2021

\author{
Hidayat \\ ORCID: https://orcid.org/0000-0002-3721-3590 \\ Universitas Muslim Nusantara Al Washliyah, Indonésia \\ E-mail: hidayat@umnaw.ac.id \\ Sukmawarti \\ ORCID: https://orcid.org/0000-0002-3700-3956 \\ Universitas Muslim Nusantara Al Washliyah, Indonésia \\ E-mail: sukmawarti@umnaw.ac.id \\ Suwanto \\ ORCID: https://orcid.org/0000-0002-9945-1236 \\ STKIP Asy Syafiiyah Internasional Medan, Indonésia \\ E-mail: Suwantompd89@gmail.com
}

\begin{abstract}
The application of Augmented Reality in the education sector has increased, the novelty of Augmented Reality technology has become a special attraction for stake holders to improve the quality of education. However, so far there is still a lack of literature studies that focus on investigating the application of Augmented Reality to students at the basic education level. This study presents a literature review on the use of Augmented Reality technology to students at the basic education level. Articles that were synthesized from 2010 to 2020 indexed by Google Schoolar were 10 articles. Using qualitative content analysis, this study attempts to answer two questions; (1) What is the impact of the application of Augmented Reality on the learning outcomes of Elementary School Students? and (2) how does the Pedagogic Perspective view Augmented Reality?
\end{abstract}

Keywords: Augmented reality; Elementary school; Education.

\section{Resumo}

A aplicação da Realidade Aumentada no setor educacional aumentou, a novidade da tecnologia de Realidade Aumentada tornou-se uma atração especial para as partes interessadas para melhorar a qualidade da educação. No entanto, até o momento ainda faltam estudos de literatura que enfoquem a investigação da aplicação da Realidade Aumentada em alunos do ensino fundamental. Este estudo apresenta uma revisão da literatura sobre o uso da tecnologia de Realidade Aumentada para alunos do ensino fundamental. Os artigos que foram sintetizados de 2010 a 2020 indexados pelo Google Schoolar foram 10 artigos. Usando a análise de conteúdo qualitativa, este estudo tenta responder a duas questões; (1) Qual o impacto da aplicação da Realidade Aumentada nos resultados de aprendizagem de Alunos do Ensino Fundamental? e (2) como a Perspectiva Pedagógica vê a Realidade Aumentada?

Palavras-chave: Realidade aumentada; Ensino fundamental; Educação.

\section{Resumen}

La aplicación de la Realidad Aumentada en el sector educativo se ha incrementado, la novedad de la tecnología de Realidad Aumentada se ha convertido en un atractivo especial para los stakeholders para mejorar la calidad de la educación. Sin embargo, hasta el momento todavía faltan estudios de literatura que se centren en investigar la aplicación de la Realidad Aumentada a los estudiantes del nivel de educación básica. Este estudio presenta una revisión de la literatura sobre el uso de la tecnología de Realidad Aumentada a estudiantes del nivel de educación básica. Los artículos que fueron sintetizados de 2010 a 2020 indexados por Google Schoolar fueron 10 artículos. Utilizando análisis de contenido cualitativo, este estudio intenta responder dos preguntas; (1) ¿Cuál es el impacto de la aplicación de la realidad aumentada en los resultados del aprendizaje de los estudiantes de primaria? y (2) ¿cómo ve la perspectiva pedagógica la realidad aumentada?

Palabras clave: Realidad aumentada; Educación primaria; Educación.

\section{Introduction}

In this modern era, technology develops in various fields, such as education, including at the basic education level. 
The use of renewable technology in elementary schools, such as Augmented Reality, continues to be developed. Augmented Reality technology is a technology that can display virtual objects in 2D and 3D in real time. Thus, for 2 decades AR has been a concern (P. Chen et al., 2017). AR was first introduced in the 1990s in airline simulation (Caudell \& Mizell, 1992), then in 2011, AR began to enter the world of education, and now AR has become a popular topic in educational research (Bacca et al., 2014) ; Ibáñez \& Delgado-Kloos, 2018) Some of the advantages for students on the use of AR, such as increased student achievement, self-confidence (Lu \& Liu, 2015), enhanced learning motivation (Chiang et al., 2014), helping students' understanding (Kamarainen et al., 2013) providing a positive attitude (Wojciechowski \& Cellary, 2013) increased satisfaction (Han et al., 2015) and enhanced spatial abilities (Higgins, 2020; Lin et al., 2013). Thus, AR has great potential for formal education (Kesim \& Ozarslan, 2012) and for informal education (Sommerauer \& Müller, 2014).

The use of Augmented Reality in the education sector is still relatively early (C. M. Chen \& Tsai, 2012; Kerawalla et al., 2006), at the basic education level the use of Augmented Reality technology is ideal (Radu et al., 2016) seeing their time as a period of play. Besides, their cognitive development is a period of concrete operational transition to Piaget's formal operations. By displaying virtual objects in 3D and 2D forms, it allows students to interact with these virtual objects (CM Chen \& Tsai, 2012), thus helping students to think concretely and abstractly (Saidin et al., 2015), so that it can motivate them to learn. Augmented Reality also supports seamless interactions between real and virtual environments and can create learning experiences (Burton et al., 2011).

The application of Augmented Reality in basic education in Indonesia is certainly not easy, there are many challenges, such as the ability of the teacher (Kerawalla et al., 2006) and even the ability of students to operate Augmented Reality technology (Wu et al., 2013) more specifically Dunleavy et al., (2009) their difficulty lies in using spatial skills, problem solving, collaborating, technological manipulation and mathematical estimation simultaneously. Then the use of Augmented Reality raises new problems such as students' physical development (Dunleavy et al., 2009).

In this study, we tried to answer several questions about the use of Augmented Reality at the basic education level.

P1: What is the impact of the application of Augmented Reality on the learning outcomes of Elementary School Students?

Q2: How does a Pedagogic Perspective view Augmented Reality?

\section{Research Method}

Several methods are used in this review study, such as selecting a set of articles according to their field (Hwang \& Tsai, 2011), then selecting articles published in reputable journals (Akçayır \& Akçayır, 2017) and using a google schoolar indexed database. The articles that were reviewed were journals with the keyword "Augmented Reality", starting from 2010 to 2020 , the number of journals obtained was 34 articles, but after an examination there were only a few journals that met the criteria of only 10 articles. The research criteria are as follows: General criteria consist of; (1) study published between 2010 and 2020; and (2) a study explaining the application of Augmented Reality technology at the primary school level.

Meanwhile, the special criteria consist of; (1) studies that report advantages, disadvantages, affordability, limitations, features, uses, challenges and effectiveness of augmented reality in basic education; (2) a study that explains applying Augmented reality that is adapted to a learning model or learning device at the basic education level; (3) a study that explains the evaluation of the use of Augmented Reality in the teaching and learning process. Then the article criteria that were not used or the exclusion criteria were; (1) the article identified is not an article by looking at her; and (2) articles that include "Augmented Reality" but actually not Augmented reality that is the focus of the discussion. 


\section{Results and Discussion}

Q1: What is the impact of the application of Augmented Reality on the learning outcomes of Elementary School Students?

The main advantage in implementing Augmented Reality in elementary school students is better learning performance and encouraging student learning motivation (Bacca et al., 2014; P. Chen et al., 2017), because Augmented Reality technology displays attractive graphics for them and there is a direct interaction between the object and the subject of learning, so that students can construct their own knowledge (Bacca et al., 2014; Zimmerman et al., 2016) and can develop their skills and knowledge (El Syed et al., 2011), Augmented Reality can display 3D objects that can be used in real time thus providing a new way to obtain more accurate information about the topic being studied (Sotiriou \& Bogner, 2008) and can help improve their performance and improve their psychomotor skills in cognitive tasks (Wu et al. ., 2013).

However, some challenges are related to students and their learning process when applying Augmented Reality technology. Cognitively, students are burdened with the amount of information they will encounter, in addition to the learning objectives they must master, the use of difficult technological devices (Chang et al., 2014) they must also master at one time. Thus, they have to do a lot of learning activities when using Augmented Reality (Wu et al., 2013). Then by applying Augmented Reality technology allows students to apply and synthesize several skills, spatial, collaboration, problem solving, technology manipulation and mathematical estimation simultaneously (Dunleavy et al., 2009). Even though the low ability of some of these skills is a challenge for student learning in implementing Augmented Reality (Kerawalla et al., 2006). Applying Augmented Reality to elementary school students, other additional learning media are needed to solve their problems and not misinterpret the real world and the virtual world (Klopfer \& Squire, 2008). The combination of the real world and the virtual world at the same time can cause confusion to students (Wu et al., 2013).

Akçayır \& Akçayır (2017) in their study showed that $60 \%$ of Augmented Reality was operated on with mobile phones, 24\% with PC (Computer) and 16\% using others, using cellphones is more ideal and practical. Using an Augmented Reality computer is too expensive and complicated to apply to elementary education classes because the process is as shown below.

Figure 1. Learning flow with Augmented Reality (Lu \& Liu, 2015).

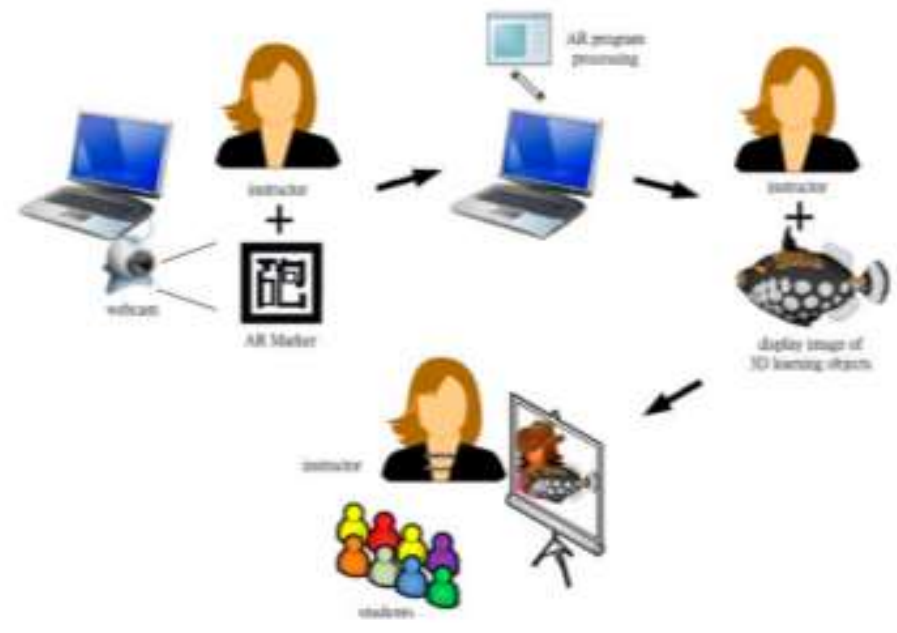

Source: Lu \& Liu (2015).

So that for elementary school students in operating Augmented Reality, a gadget that is more appropriate to use is a 
cellphone (Furió et al., 2013), because it is easier to use, more practical, more interactive, and more effective (Hwang et al., 2012). The ease and practicality are what make it possible for students to not be able to control the time to use cellphones. Discipline when using cellphones is not good enough to lead to dependence or addiction to playing cellphones so that it will cause students to become lazy (Sobon et al., 2020) and have a negative effect on the growth of student knowledge and learning activities (Salehudin et al., 2020), What's more Augmented Reality design in the form of game education is more preferred and attracts students' attention to basic education (Lu \& Liu, 2015), so it needs deeper attention when designing Augmented Reality in learning. However, elementary school students need gestures for their growth (Stork \& Sanders, 2008).

Then the marker or image to bring up virtual objects is the main component in using Augmented Reality, so that it can display objects/ learning media without having to go to the location where the object is located. Of course this is one of the advantages of Augmented Realty technology, but this provides a new meaning for students to understand the location (Wu, 2013). So that learning does not only occur in the classroom, it is better if the teacher as the instructor designer as well as designing markers or images that can be found where the objects are actually located (Klopfer \& Sheldon, 2012). For example, showing how to wash hands properly and correctly, using pictures that people often use as signatures for washing hands, so that students can better master the expected learning objectives. However, the most important thing in designing markers or

images must be able to be scanned well, because if the images are not well identified, students will have difficulty using Augmented Reality technology (Muñoz-Cristóbal et al., 2015).

\section{Q2: How does a Pedagogic Perspective view Augmented Reality?}

The application of Augmented Reality in the classroom raises several pedagogical problems that need to be considered, such as many previous educational innovations that have not been well mastered, so that mastery of AR in the classroom can face new obstacles both from schools in providing facilities and teachers' mastery of Augmented Reality (Wu et al. al., 2013). Involving Augmented Reality in learning, of course, requires student-centered learning methods, this will create a gap between the learning methods needed and the learning methods currently being carried out. Another obstacle that will be faced in implementing AR is the curriculum, such as the amount of certain learning content that must be achieved within a certain time (Kerawalla et al., 2006). The inflexibility of Augmented Reality will lead to other pedagogical problems such as file content and the order that has been designed, which cannot be changed to accommodate the needs or achievements of students (Wu et al., 2013).

So far, the learning strategy has been designed based on the needs of students and the achievement of student learning outcomes in accordance with the curriculum. Even though the learning strategy is declared effective, it is necessary to reexamine it when collaborating with Augmented Reality technology. Ibáñez \& Delgado-Kloos (2018) suggest that Role Playing learning strategies can be collaborated with Augmented reality by utilizing the advantages of AR technology which can display various texts, images, 3D objects and animations (C. M. Chen \& Tsai, 2012). The presentation of attractive 3D objects will provide a new learning atmosphere and enjoyment for students ( $\mathrm{Lu} \& \mathrm{Liu}, 2015)$ in following the learning process. On the other hand, Bacca et al. (2014) suggest that constructivism learning strategies can also be collaborated with Augmented Reality technology, assuming that interaction with Augmented Reality gives students the freedom to find information, thus potentially increasing knowledge construction activities in students. However, further studies need to be done to find how Augmented Reality can be designed to help build student knowledge (Zydney \& Warner, 2016) and how to measure it (Bacca et al., 2014).

The virtual appearance of an attractive 3D object and the same as the original object can improve student understanding (Yoon et al., 2017). Even though it is only a simulation of the original object, AR allows it to provide a learning 
experience for students, so that student participation in AR can increase students' motivation and spatial abilities. (Han et al., 2015). Understanding certain objects and natural phenomena that are difficult to obtain in the real world will provide a very valuable learning experience for students. For example, urban children who are studying the ecosystem in rice fields, for urban children, rice fields are a step for them. When this interaction occurs, students can deepen their understanding and construct their knowledge (Han et al., 2015).

\section{Conclusion and Suggestions}

The use of Augmented Reality technology for basic education students can have a positive impact and a negative impact. Although the influence is direct and indirect. The use of Augmented Reality in elementary school students still has to consider the needs and readiness of students, as well as existing readiness such as facilities and teacher abilities. From a pedagogical point of view, Augmented Reality technology is very supportive for the implementation of learning activities, it can create student learning experiences directly. However, students still have to consider the concept of the difference between the real world and the virtual world.

\section{References}

Akçayır, M., \& Akçayır, G. (2017). Advantages and challenges associated with augmented reality for education: A systematic review of the literature. Educational Research Review, 20, 1-11. https://doi.org/10.1016/j.edurev.2016.11.002

Bacca, J., Baldiris, S., Fabregat, R., Graf, S., \& Kinshuk. (2014). International Forum of Educational Technology \& Society Augmented Reality Trends in Education : A Systematic Review of Research and Applications. Educational Technology, 17(4), 133-149. https://www.jstor.org/stable/jeductechsoci.17.4.133

Burton, E. P., Frazier, W., Anneta, L., Lamb, R., Cheng, R., \& Chmiel, M. (2011). Modeling Augmented Reality Games with Preservice Elementary and Secondary Science Teachers. Journal of Technology and Theacher Ecucation, 19(3), 303-329. https://www.learntechlib.org/primary/p/37136/.

Caudell, T. P., \& Mizell, D. W. (1992). Augmented Reality: An Application of Heads-Up Display Technology to Manual Manufacturing Processes. Proceedings of the Twenty-Fifth Hawai Internasional Comference on System Sciences.

Chang, K. E., Chang, C. T., Hou, H. T., Sung, Y. T., Chao, H. L., \& Lee, C. M. (2014). Development and behavioral pattern analysis of a mobile guide system with augmented reality for painting appreciation instruction in an art museum. Computers and Education, 71 , $185-197$. https://doi.org/10.1016/j.compedu.2013.09.022

Chen, C. M., \& Tsai, Y. N. (2012). Interactive augmented reality system for enhancing library instruction in elementary schools. Computers and Education, 59(2), 638-652. https://doi.org/10.1016/j.compedu.2012.03.001

Chen, P., Liu, X., Cheng, W., \& Huang, R. (2017). A review of using Augmented Reality in Education from 2011 to 2016. 13-19. https://doi.org/10.1007/978981-10-2419-1

Chiang, T. H. C., Yang, S. J. H., \& Hwang, G.-J. (2014). An Augmented Reality-based Mobile Learning System to Improve Students' Learning Achievements and Motivations in Natural Science Inquiry Activities. Educational Technology \& Society, 17(4), 352-365. https://doi.org/https://www.jstor.org/stable/jeductechsoci.17.4.352

Dunleavy, M., Dede, C., \& Mitchell, R. (2009). Affordances and limitations of immersive participatory augmented reality simulations for teaching and learning. Journal of Science Education and Technology, 18(1), 7-22. https://doi.org/10.1007/s10956-008-9119-1

El Syed, N. A. M., Zayed, H. H., \& Sharawy, M. . (2011). ARSC: Augmented Reality Student Card. Computers \& Education, 56(4), 1045-1061. https://doi.org/doi:10.1016/j.compedu.2010.10.019

Furió, D., González-Gancedo, S., Juan, M. C., Seguí, I., \& Rando, N. (2013). Evaluation of learning outcomes using an educational iPhone game vs. traditional game. Computers and Education, 64, 1-23. https://doi.org/10.1016/j.compedu.2012.12.001

Han, J., Jo, M., Hyun, E., \& So, H. jeong. (2015). Examining young children's perception toward augmented reality-infused dramatic play. Educational Technology Research and Development, 63(3), 455-474. https://doi.org/10.1007/s11423-015-9374-9

Higgins, J. (2020). Cognising With Others in the We-Mode: a Defence of 'First-Person Plural' Social Cognition. Review of Philosophy and Psychology, 2005, 1-22. https://doi.org/10.1007/s13164-020-00509-2

Hwang, G. J., \& Tsai, C. C. (2011). Research trends in mobile and ubiquitous learning: A review of publications in selected journals from 2001 to 2010. British Journal of Educational Technology, 42(4), 65-70. https://doi.org/10.1111/j.1467-8535.2011.01183.x

Hwang, G. J., Tsai, C. C., Chu, H. C., Kinshu, \& Chen, C. Y. (2012). A context-aware ubiquitous learning approach to conducting scientific inquiry activities 
in a science park. Australasian Journal of Educational Technology, 28(5), 931-947. https://doi.org/10.14742/ajet.825

Ibáñez, M. B., \& Delgado-Kloos, C. (2018). Augmented reality for STEM learning: A systematic review. Computers and Education, 5(2), 109-123. https://doi.org/10.1016/j.compedu.2018.05.002

Kamarainen, A. M., Metcalf, S., Grotzer, T., Browne, A., Mazzuca, D., Tutwiler, M. S., \& Dede, C. (2013). EcoMOBILE: Integrating augmented reality and probeware with environmental education field trips. Computers and Education, 68, 545-556. https://doi.org/10.1016/j.compedu.2013.02.018

Kerawalla, L., Luckin, R., Seljeflot, S., \& Woolard, A. (2006). "Making it real": Exploring the potential of augmented reality for teaching primary school science. Virtual Reality, 10(3-4), 163-174. https://doi.org/10.1007/s10055-006-0036-4

Kesim, M., \& Ozarslan, Y. (2012). Augmented Reality in Education: Current Technologies and the Potential for Education. Procedia - Social and Behavioral Sciences, 47(222), 297-302. https://doi.org/10.1016/j.sbspro.2012.06.654

Klopfer, E., \& Sheldon, J. (2012). Augmenting your own reality: Student authoring of science-based augmented reality games. In R. Ciglič, B. Komac, A. Steinfuhrer, \& Z. Matija (Eds.), Natural hazards and education in Europe (pp. 85-94). https://doi.org/10.1002/yd

Klopfer, E., \& Squire, K. (2008). Environmental detectives-the development of an augmented reality platform for environmental simulations. Educational Technology Research and Development, 56(2), 203-228. https://doi.org/10.1007/s11423-007-9037-6

Lin, H. C. K., Chen, M. C., \& Chang, C. K. (2013). Assesing the effectiveness of learning solid geometru by using an augmented reality-assisted learning system. Interactive Learning Enviroments, 23(6), 799-810. https://doi.org/https://doi.org/10.1080/10494820.2013.817435

Lu, S. J., \& Liu, Y. C. (2015). Integrating augmented reality technology to enhance children's learning in marine education. Environmental Education Research, 21(4), 525-541. https://doi.org/10.1080/13504622.2014.911247

Muñoz-Cristóbal, J. A., Jorrín-Abellan, I. M., Asensio-Peréz, J. I., Martínez-Monés, A., Prieto, L. P., \& Dimitriadis, Y. (2015). Supporting teacher orchestration in ubiquitous learning environments: A study in primary education. IEEE Transactions on Learning Technologies, 8(1), 83-97. https://doi.org/10.1109/TLT.2014.2370634

Radu, I., McCarthy, B., \& Kao, Y. (2016). Discovering educational augmented reality math applications by prototyping with elementary-school teachers. Proceedings - IEEE Virtual Reality, July, 271-272. https://doi.org/10.1109/VR.2016.7504758

Saidin, N. F., Halim, N. D. A., \& Yahaya, N. (2015). A review of research on augmented reality in education: Advantages and applications. International Education Studies, 8(13), 1-8. https://doi.org/10.5539/ies.v8n13p1

Salehudin, M., Marniah, \& Hariati. (2020). Siswa SD Menggunakan Smartphone Dalam Pembelajaran Online. IBTIDA': Media Komunikasi Hasil Penelitian Pendidikan Guru Madrasah Ibtidaiyah, 01(02), 229-241.

Sobon, K., Mangundap, J. M., \& Walewangko, S. (2020). Pengaruh Penggunaan Smartphone Terhadap Motivasi Belajar Siswa Sekolah Dasar Di Kecamatan Mapanget Kota Manado. Autentik: Jurnal Pengembangan Pendidikan Dasar, 3(2), 97-106. https://doi.org/10.36379/autentik.v3i2.38

Sommerauer, P., \& Müller, O. (2014). Augmented reality in informal learning environments: A field experiment in a mathematics exhibition. Computers and Education, 79(2014), 59-68. https://doi.org/10.1016/j.compedu.2014.07.013

Sotiriou, S., \& Bogner, F. X. (2008). Visualizing the Invisible: Augmented Reality as an Innovative Science Education Scheme. American Scientific Publishers, 1(1), 114-122. https://doi.org/https://doi.org/10.1166/asl.2008.012

Stork, S., \& Sanders, S. W. (2008). Physical Education in Early Childhood. The Elementary School Journal, 108(3). https://doi.org/https://doi.org/10.1086/529102

Wojciechowski, R., \& Cellary, W. (2013). Evaluation of learners' attitude toward learning in ARIES augmented reality environments. Computers and Education, 68, 570-585. https://doi.org/10.1016/j.compedu.2013.02.014

Wu, H. K., Lee, S. W. Y., Chang, H. Y., \& Liang, J. C. (2013). Current status, opportunities and challenges of augmented reality in education. Computers and Education, 62, 41-49. https://doi.org/10.1016/j.compedu.2012.10.024

Yoon, S., Anderson, E., Lin, J., \& Elinich, K. (2017). How Augmented Reality Enables Conceptual Understanding of Challenging Science Content. Educational Technology \& Society2, 20(1), 156-168. https://www.jstor.org/stable/jeductechsoci.20.1.156

Zimmerman, H. T., Land, S. M., \& Jung, Y. J. (2016). Using augmented reality to support children's situational interest and science learning during contextsensitive informal mobile learning. Advances in Intelligent Systems and Computing, 406, 101-119. https://doi.org/10.1007/978-3-319-26518-6_4

Zydney, J. M., \& Warner, Z. (2016). Mobile apps for science learning: Review of research. Computers and Education, 94, 1-17. https://doi.org/10.1016/j.compedu.2015.11.001 